ORIGINAL ARTICLE

\title{
静脈血栓塞栓症を合併した原発性肺癌患者の臨床的検討
}

\author{
杉野圭史 1 ・磯部和順 1 ・菊地 直 1 村松陽子 1 ・ \\ 佐野 剛 $1 \cdot$ 高井雄二郎 $1 \cdot$ 本間 栄1
}

\section{Clinical Analysis of Lung Cancer Associated with Venous Thromboembolism}

\author{
Keishi Sugino1; Kazutoshi Isobel; Naoshi Kikuchi1; Yoko Muramatsu; \\ Go Sano1; Yujiro Takai1; Sakae Homma1 \\ ${ }^{1}$ Department of Respiratory Medicine, Toho University Omori Medical Center, Japan.
}

\begin{abstract}
Objective. The aim of this study was to assess the characteristic clinical features of lung cancer associated with venous thromboembolism (VTE). Patients and Methods. We conducted a retrospective study of 12 patients who were diagnosed as having lung cancer associated with VTE between April 2003 and April 2007. Clinical features, treatments and prognoses were evaluated. Results. Among 230 patients with lung cancer, 12 patients ( 8 men, 4 women; mean age 66.1 years) were given a diagnosis of having VTE (5.2\%). Of these 8 were adenocarcinoma, 2 squamous cell carcinoma, and 2 small cell lung cancer. All patients received chemotherapy, 4 received long-term corticosteroid therapy, 6 had prolonged immobility and 1 had deep vein thrombosis. Anticoagulants were given to 11 patients, with improved outcome in 6 , while the condition deteriorated in 4 and was unchanged in 1. Causes of death were lung cancer in 7, pulmonary thromboembolism in 3 and other disorders in 2, respectively. Median survival in stage III and IV lung cancer with VTE was significantly worse than that in lung cancer not associated with VTE (35 weeks vs. 49 weeks; $\mathrm{p}<0.008$ ). Conclusion. Lung cancer associated with VTE has a poor prognosis, and is frequently resistant to anticoagulants and chemotherapeutic agents.
\end{abstract}

(JJLC. 2009;49:151-156)

KEY WORDS — Primary lung cancer, Venous thromboembolism, Pulmonary thromboembolism, Deep vein thrombosis, Prognosis

Reprints: Keishi Sugino, Department of Respiratory Medicine, Toho University Omori Medical Center, 6-11-1 Omori-nishi, Ota-ku, Tokyo 143-8541, Japan (e-mail: keishi_sugino@ybb.ne.jp).

Received October 6, 2008; accepted November 25, 2008.

要旨一一目的. 原発性肺癌と静脈血栓塞栓症の合併例に 関する臨床的特徵を明らかにする. 対象および方法. 2003 年 4 月から 2007 年 4 月までに当科に入院した静脈血栓 塞栓症を合併した原発性肺癌 12 症例を対象に，患者背 景, 臨床像, 治療ならびに予後について retrospective に検討した. 結果. 原発性肺癌 230 例中, 12 例 (5.2\%)に 静脈血栓塞栓症の合併を認めた。性別は男性 8 例, 女性 4 例で, 平均年齢は $66.1 \pm 11.2$ 歳であった. 組織型は腺癌 が 8 例，扁平上皮癌と小細胞癌が 2 例ずつであった．全 例で抗癌剤が投与されており，4例にステロイドが長期 投与されていた。また長期臥床が 6 例，エコノミークラ
ス症候群が 1 例に認められた。血栓塞栓症の治療は，11 例で抗凝固療法を行い, 6 例が改善, 4 例が悪化, 1 例が 不変であった，死因は，肺癌が 7 例，肺血栓塞栓症が 3 例，その他の原因が 2 例であった. 全 12 例の生存期間中 央值は 35 週と非合併例の 49 週に比べて有意に予後不良 であった．結論．静脈血栓塞栓症を合併した原発性肺癌 症例では，抗癌剤治療に抵抗性を示し，さらに抗凝固療 法の効果も乏しく，非合併例より予後不良であった。 索引用語——原発性肺癌, 静脈血栓塞栓症, 肺血栓塞栓 症, 深部静脈血栓症, 予後
1東邦大学医療センター大森病院呼吸器内科.

別刷請求先 : 杉野圭史, 東邦大学医療センター大森病院呼吸器内

科，＝143-8541 東京都大田区大森西 6-11-1(e-mail: keishi_sugino @ybb.ne.jp).

受付日：2008 年 10 月 6 日，採択日：2008 年 11 月 25 日. 


\section{はじめに}

悪性腫瘍患者に静脈血栓塞栓症（venous thromboembolism：VTE）を合併することは古くから知られてお り, 1 また抗癌剤治療もVTE発症の危険因子となり得 ると考えられている. 2 一方, 最近では原発性肺癌症例の 約 $3 \%$ にVTE を認め, 予後不良因子であったとする報 告や, ${ }^{3}$ 扁平上皮癌に比べて腺癌において VTE 合併頻 度が高いとする報告などがみられるようになった. 4 し かし, VTE を合併した原発性肺癌患者の臨床像の詳細な 検討による，血栓予防ならびに積極的な抗凝固療法の効 果に関する報告は少ない.

本検討では抗癌剂治療を行った臨床病期 III 期以上の 原発性肺癌症例のうち, VTE を合併した症例の臨床像な らびに治療法について検討した.

\section{対象および方法}

2003 年 4 月から 2007 年 4 月までの 4 年間に, 原発性 肺癌の診断で当院呼吸器内科に入院した臨床病期 III 以 上の患者 230 症例のうち, VTE を合併した 12 症例を対 象に, 患者背景, 臨床像, 治療ならびに予後について, retrospectiveに検討した。治療開始時の performance status (PS) ならびに臨床病期は日本肺癌学会取扱い規約 に準じた. 5 肺癌の確定診断は, 気管支鏡検査による細胞 診および組織診, 喀痰細胞診, 剖検による組織診のいず れかで行われた. 一方, 肺血栓塞栓症 (pulmonary thromboembolism : PTE) の確定診断は, 胸部造影 CT, 肺血 流シンチグラフィーで行い, 深部静脈血栓症 (deep vein thrombosis：DVT）の確定診断は四肢血管エコーによっ て行われた.
デー夕解析結果は, 平均值 \pm 標準偏差で示し, 有意差 水準を $5 \%$ 未満とした. また予後は Kaplan-Meier 法で 算出し，その有意差検定には $\log$ rank testを用いた。 な お統計解析ソフトは StatView ${ }^{\circledR} 5.0$ (米国 SAS Institute Inc.）を使用した

\section{結 果}

12 症例の性別は男性 8 例, 女性 4 例と男性に多く, 平 均年齢は $66.1 \pm 11.2$ 歳であった. 喫煙指数は $1130 \pm 952$ で, 重喫煙者が多かった，組織型は腺癌が 8 例, 扁平上 皮癌と小細胞癌が 2 例ずつで, 臨床病期は IIIA/IIIB/ IV : 4/3/5 例であった. またVTE 発症時の PS は $1 / 2 / 3 /$ $4: 3 / 3 / 4 / 2$ 例であった. 基礎疾患は, 12 例中 6 例 (50\%) に認められ，その内訳は高血圧おょび chronic obstructive pulmonary disease（COPD）が 2 例ずつ, 間質性肺 炎, 心筋梗塞, 心房細動がそれぞれ 1 例ずつであった (Table 1).

VTE の病型の内訳は, PTE 型 7 例, DVT 型 5 例で あった. VTE 発症時の臨床症状は, PTE 型の 7 例中 6 例が呼吸困難, 1 例が上肢疼痛, DVT 型の 5 例中 2 例が 下肢疼痛，全例が下肢腫脹を伴っていた，室内気下の動 脈血酸素分圧は, PTE 型, DVT 型でそれぞれ $75.0 \pm 21.5$ torr, $81.9 \pm 20.4$ torr と PTE 型で低い傾向にあった. PTE を併発した 7 例中 4 例で, 長期のステロイド投与が行わ れており,さらに 4 例が全身状態悪化や腰椎転移による 長期臥床 (PS 3〜4)の状態であった.また, granulocytecolony stimulating factor（G-CSF）の使用は, PTE 型が 5 例, DVT型が 1 例であった。一方, DVTを併発した 5 例中 2 例が長期臥床, 1 例がエコノミークラス症候群 (Case 8) で発症していた. 原発性肺癌の診断以前にVTE

Table 1. Clinical Features (1)

\begin{tabular}{cccrccccc}
\hline Case & Age & Sex & \multicolumn{1}{c}{ S.I. } & Histology & cTNM & Stage & PS & Underlying disease \\
\hline 1 & 71 & F & 0 & AD & T4N0M0 & III & 1 & HT \\
2 & 66 & M & 3000 & AD & T1N3M0 & IIIB & 1 & None \\
3 & 68 & M & 800 & AD & T4N0M1 & IV & 4 & None \\
4 & 72 & F & 0 & AD & T4N2M1 & IV & 2 & None \\
5 & 52 & M & 900 & AD & T4N2M1 & IV & 4 & None \\
6 & 77 & M & 2200 & SCLC & T2N2M0 & IIIA & 3 & OMI \\
7 & 70 & M & 1820 & SCC & T4N3M1 & IV & 3 & HT, Af \\
8 & 47 & M & 400 & AD & T2N3M0 & IIIB & 2 & None \\
9 & 80 & M & 2200 & AD & T1N2M0 & IIIA & 3 & COPD \\
10 & 64 & M & 800 & SCC & T3N1M0 & IIIA & 2 & IP \\
11 & 77 & F & 800 & SCLC & T2N2M0 & IIIA & 3 & COPD \\
12 & 49 & F & 640 & AD & T4N3M1 & IV & 1 & None \\
\hline
\end{tabular}

F: female, M: male, S.I.: smoking index, AD: adenocarcinoma, SCLC: small cell lung cancer, SCC: squamous cell carcinoma, PS: performance status, HT: hypertension, OMI: old myocardial infarction, Af: atrial filtration, COPD: chronic obstructive pulmonary disease, IP: interstitial pneumonia. 
Table 2. Clinical Features (2)

\begin{tabular}{|c|c|c|c|c|c|c|c|c|}
\hline Case & $\begin{array}{l}\text { Type of } \\
\text { VTE }\end{array}$ & Symptom & $\begin{array}{l}\mathrm{PaO}_{2} / \mathrm{PaCO}_{2} \\
\text { (torr) }\end{array}$ & $\begin{array}{l}\text { Platelet counts be- } \\
\text { fore chemotherapy } \\
\qquad\left(\times 10^{4} / \mu \mathrm{l}\right)\end{array}$ & $\begin{array}{l}\text { Prolonged } \\
\text { immobility }\end{array}$ & $\begin{array}{c}\text { Corticosteroid } \\
\text { therapy }\end{array}$ & $\begin{array}{l}\text { Administration } \\
\text { of G-CSF }\end{array}$ & $\begin{array}{l}\text { Duration from diagnosis of } \\
\text { lung cancer to the onset of } \\
\text { VTE (month) }\end{array}$ \\
\hline 1 & PTE & Dyspnea & $61.9 / 37.5$ & 30.4 & - & - & + & -1 \\
\hline 2 & PTE & Arm pain & $74.9 / 33$ & 26.4 & - & - & + & 2 \\
\hline 3 & PTE & Dyspnea & $65.8 / 39.6$ & 34.6 & + & + & + & 9 \\
\hline 4 & PTE & Dyspnea & $103 / 33.4$ & 18.3 & - & + & - & 2 \\
\hline 5 & PTE & Dyspnea & $49.6 / 41.2$ & 27.8 & + & + & - & 5 \\
\hline 6 & PTE & Dyspnea & $106 / 20.7$ & 18.6 & + & - & + & 17 \\
\hline 7 & PTE & Dyspnea & $63.7 / 35.4$ & 27.2 & + & + & + & 4 \\
\hline 8 & DVT & $\begin{array}{l}\text { Leg pain, } \\
\text { edema }\end{array}$ & $74.9 / 33.7$ & 46.7 & - & - & - & -1 \\
\hline 9 & DVT & Leg edema & $69.2 / 31.4$ & 22.5 & + & - & - & 3 \\
\hline 10 & DVT & Leg edema & $116 / 42$ & 39.4 & - & - & - & 1 \\
\hline 11 & DVT & Leg edema & $65.1 / 31$ & 20.9 & + & - & + & 7 \\
\hline 12 & DVT & $\begin{array}{l}\text { Leg pain, } \\
\text { edema }\end{array}$ & $84.2 / 38.4$ & 30.5 & - & - & - & 1 \\
\hline
\end{tabular}

VTE: venous thromboembolism, PTE: pulmonary thromboembolism, DVT: deep vein thrombosis, G-CSF: granulocyte-colony stimulating factor.

と診断された症例は 2 例(PTE 1 例, DVT 1 例)のみで, 残り 10 例において, 原発性肺癌の診断から血栓塞栓症発 症までの期間中央值は 3.5 ヶ月であった（Table 2).

原発性肺癌に対する治療は, 非小細胞肺癌の 10 例中 9 例 (Case 1〜 5, 7, 8, 10, 12) が, 1st line としてプラチ ナ系抗癌剂である carboplatin (CBDCA) を含む併用療法 を受けていた。残りの 1 例（Case 9) は高齢かつ PS 不良 のため, docetaxel 単剂投与であった。一方, 小細胞肺癌 の 2 例 (Case 6, 11) はともに CBDCA と etoposide の併 用療法を受けていた。これら初回治療の効果判定では,

PR 1 例, SD 3 例, PD 8 例と 12 例中 8 例 $(66.7 \%)$ が治 療抵抗性を示した。またVTE発症までの抗癌剤治療歴 は, 1st line 4 例, 2nd line 4 例, 3rd line 1 例, 4 th line 2 例, 5th line 1 例であった.

VTE に対する治療は, 血痰が持続していた 1 例を除い て 11 例でワーファリンによる抗凝固療法が行われてい た.また PTE予防目的で, 4 例に下大静脈フィルターが 留置されていた。抗凝固療法ならびに下大静脈フィル ター留置を併用した症例が 4 例, 抗凝固療法単独が 6 例, 血栓溶解療法（ウロキナーゼ） と抗凝固療法の併用が 1 例であった．治療効果は, 11 例中 6 例で改善, 1 例で不 変, 4 例で悪化を認めた. ウロキナーゼを使用した 1 例 (Case 3) は, PTE 発症時に, 一時血圧低下, ショック状 態であったが, ウロキナーゼ 1 日 72 万単位を 5 日間静脈 投与したところ, 全身状態ならびに肺動脈血流の改善を 認めた.

一方, 死因としては, 肺癌の進展が 7 例, PTEが 3 例, その他の原因として, 敗血症, 間質性肺炎がそれぞ れ 1 例ずつであった。 また, VTE 発症後の生存期間は,
治療後, 改善を認めた 6 例中 5 例が肺癌の進展により $25.0 \pm 31.5$ 週で, 悪化あるいは不変であった 5 例中 3 例 がPTEにより $18.7 \pm 6.1$ 週でそれぞれ死亡していた (Table 3). 全 12 症例の生存期間中央值は 35 週と VTE 非合 併 218 症例の 49 週に比べて有意に予後不良であった (Figure 1).

\section{考 察}

悪性腫瘍患者にVTE を合併することは, Trousseau 症候群として古くから知られており, 特に原発性肺癌と の合併が多く, 全体の約 $25 \%$ を占めるとされている. ${ }^{1}$ このように高率に合併する要因として, 癌由来の凝固能 充進状態に加えて, 抗癌剂治療, 放射線治療, 手術, 中 心静脈カテーテル留置, 全身状態覀化による長期臥床な どが挙げられる。本検討でも, 全例, 抗癌剤治療を受け ており,さらに長期臥床の状態や中心静脈カテーテル留 置，ステロイドの使用などが認められた。また，悪性腫 瘍が血栓症を引き起こすメカニズムとしては，1）ムチン 産生腺癌によるプロコアグラント分泌, 6 2) ムチンによ る血小板活性化, 7 3) 腫瘍により活性化された単球/マク ロファージが放出する炎症性サイトカイン (IL-1, IL-6, tumor necrosis factor)による血管内皮障害や組織因子の 活性化8 などが指摘されている.さらに肺癌の組織型別 によるVTEの頻度の違いも, Blom ら4により報告され ており, 扁平上皮癌に比べて腺癌の方が, より高い危険 因子であることが示されている。 また抗癌剤あるいは放 射線治療中の症例や転移を伴っている症例では, さらに 危険率が高まるとしている，本検討においても，VTE 合併肺癌 12 例中 8 例が腺癌と最多で, 全腺癌患者の 
Table 3. Treatments and Outcome

\begin{tabular}{|c|c|c|c|c|c|c|c|}
\hline Case & Type of VTE & Chemotherapy for lung cancer & $\begin{array}{l}\text { Efficacy of } \\
\text { first line } \\
\text { chemotherapy }\end{array}$ & $\begin{array}{l}\text { Therapy for } \\
\text { VTE }\end{array}$ & $\begin{array}{l}\text { Outcome of } \\
\text { VTE }\end{array}$ & Cause of death & $\begin{array}{l}\text { Survival after } \\
\text { the onset of } \\
\text { VTE (week) }\end{array}$ \\
\hline 1 & PTE & $\mathrm{CBDCA}+\mathrm{DOC}$ & $\mathrm{SD}$ & $\mathrm{H}, \mathrm{W}, \mathrm{F}$ & deteriorated & PTE & 20 \\
\hline 2 & PTE & $\mathrm{CBDCA}+\mathrm{DOC}$ & $\mathrm{PD}$ & $\mathrm{H}, \mathrm{W}, \mathrm{F}$ & deteriorated & PTE & 12 \\
\hline 3 & PTE & $\begin{array}{c}\mathrm{CBDCA}+\mathrm{DOC} \Rightarrow \mathrm{CDDP}+\mathrm{VRB} \\
\Rightarrow \mathrm{CDDP}+\mathrm{TS}-1 \Rightarrow \\
\mathrm{CBDCA}+\mathrm{GEM}\end{array}$ & $\mathrm{PD}$ & $\mathrm{H}, \mathrm{W}, \mathrm{UK}$ & improved & Lung cancer & 16 \\
\hline 4 & PTE & $\mathrm{CBDCA}+\mathrm{PAC} \Rightarrow \mathrm{GEM}$ & $\mathrm{PD}$ & $\mathrm{H}, \mathrm{W}$ & deteriorated & PTE & 24 \\
\hline 5 & PTE & $\begin{array}{c}\mathrm{CBDCA}+\mathrm{DOC} \Rightarrow \text { Gefitinib } \\
\mathrm{CBDCA}+\mathrm{VP}-16 \Rightarrow\end{array}$ & $\mathrm{PD}$ & $\mathrm{H}, \mathrm{W}$ & improved & Lung cancer & 4 \\
\hline 6 & PTE & $\begin{array}{c}\mathrm{CPT}-11 \stackrel{\mathrm{AMR}}{\mathrm{CBDCA}+\mathrm{DOC}} \\
\Rightarrow \mathrm{ANV}\end{array} \Rightarrow$ & $\mathrm{PD}$ & $\mathrm{H}, \mathrm{W}$ & improved & Lung cancer & 5 \\
\hline 7 & PTE & $\mathrm{CBDCA}+\mathrm{DOC}$ & PR & $\mathrm{H}, \mathrm{W}$ & improved & Sepsis & 8 \\
\hline 8 & DVT & $\begin{array}{l}\mathrm{CBDCA}+\mathrm{DOC} \Rightarrow \\
\mathrm{CPT}-11+\mathrm{GEM}\end{array}$ & $\mathrm{PD}$ & $\mathrm{H}, \mathrm{W}, \mathrm{F}$ & deteriorated & Lung cancer & 26 \\
\hline 9 & DVT & $\mathrm{DOC} \Rightarrow \mathrm{UFT} \Rightarrow \mathrm{TS}-1$ & $\mathrm{PD}$ & $\mathrm{H}, \mathrm{W}, \mathrm{F}$ & improved & Lung cancer & 80 \\
\hline 10 & DVT & $\begin{array}{c}\text { CBDCA+DOC } \Rightarrow \\
\text { CPT- }-11+\text { GEM }\end{array}$ & $\mathrm{SD}$ & - & - & IP & 32 \\
\hline 11 & DVT & $\begin{array}{c}\mathrm{CDDP}+\mathrm{VP}-16 \Rightarrow \mathrm{CPT}-11 \Rightarrow \\
\mathrm{AMR} \Rightarrow \mathrm{ACNU}+\mathrm{PAC}\end{array}$ & $\mathrm{SD}$ & $\mathrm{H}, \mathrm{W}$ & improved & Lung cancer & 20 \\
\hline 12 & DVT & $\mathrm{CBDCA}+\mathrm{DOC}$ & $\mathrm{PD}$ & $\mathrm{H}, \mathrm{W}$ & unchanged & Lung cancer & 4 \\
\hline
\end{tabular}

VTE: venous thromboembolism, PTE: pulmonary thromboembolism, DVT: deep vein thrombosis, CBDCA: carboplatin, DOC: docetaxel, VRB: vinorelbine, CDDP: cisplatin, TS-1: tegafur, gimeracil, oteracil potassium, GEM: gemcitabine, PAC: paclitaxel, VP-16: etoposide, CPT-11: irinotecan, AMR: amrubicin, ANV: adriamycin+nimustine+vindesine, UFT: tegafur-uracil, ACNU: nimustine, SD: stable disease, PD: progressive disease, PR: partial response, H: heparin, W: warfarin, F: filter, UK: urokinase, IP: interstitial pneumonia.

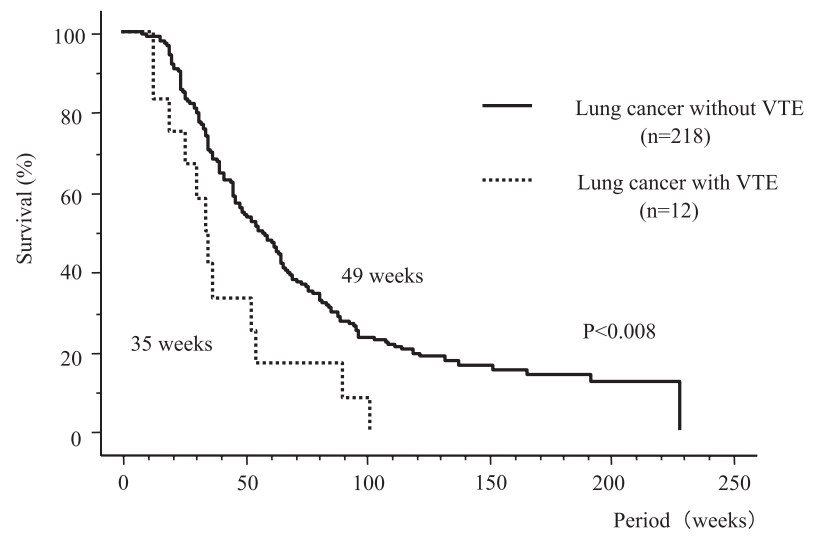

Figure 1. Survival curve in 2 groups of lung cancer patients (stage III and IV). Solid line; lung cancer without VTE, $n=218$. Dotted line; lung cancer with VTE, $n=12$. Survival rate in lung cancer with VTE was significantly decreased than that in lung cancer not associated with VTE ( 35 weeks vs. 49 weeks; p<0.008).

6.6\%を占めていた.これは扁平上皮癌の $3.7 \%$, 小細胞癌 の $3.8 \%$ と比べても高頻度であり, 血栓の発症機序にム チン産生腺癌によるプロコアグラント分泌やムチンによ る血小板活性化が強く関与している可能性を支持する結 果と考えられた。一方で, 抗癌剤治療もVTE発症の危険 因子となり得るが，これは抗癌剤により障害を受けた腫
瘍細胞から放出されるプロコアグラントやサイトカイン および血管内皮障害による凝固能立進に加えて, 肝毒性 による抗凝固作用の低下などが示唆されている. 2 また, Khorana $5^{9}$ は少なくとも 1 サイクルの抗癌剤治療を受 けた癌患者 3,003 例を対象に, VTEの危険因子に関して 多変量解析を用いて検討したところ, 上部消化器癌, 肺 癌であること, 抗癌剂治療前の血清中の血小板数が $350,000 / \mathrm{mm}^{3}$ 以上であること, へモグロビン值が $10 \mathrm{~g} / \mathrm{dl}$ 未満であること， G-CSF の使用歴があることがVTEの 発症に強く関連していることを示唆している. 本検討で は, 抗癌剤治療前の血清中の血小板数増多を認めたもの が 12 例中 2 例のみで, ヘモグロビン值が $10 \mathrm{~g} / \mathrm{dl}$ 未満の 症例はみられなかった. 一方, G-CSF は 12 例中 6 例で使 用されており,うち 5 例が PTE を合併していた. 特に G$\mathrm{CSF}$ は, 血小板凝集能の充進をきたすことが報告されて おり, 10 抗癌剤治療による血管内皮の損傷と PS の低下 による血流停滞などが加わることにより，血栓の形成を 促進させる可能性がある。

静脈血栓は, 血液凝固能の立進, 線溶能の低下ならび に血液の停滞が主な要因となって形成され, フィブリン と赤血球が主成分の赤色血栓である。したがって治療と しては抗凝固剤が使用されるのが一般的である。しかし ながら, 癌患者におけるワーファリンの効果はそしく, 諸家ら11,12の報告では, ワーファリンの維持療法中に約 
$1 / 3$ の患者に再発および出血の副作用を認めている。一 方で最近，低分子へパリンの有効性が示唆されている. Lee ら13は, 676 例の VTE 合併悪性腫瘍患者を対象に, 低分子ヘパリンであるダルテパリン単独投与群とワー ファリン投与群に分けて, 6 ヶ月後の有症状の VTE の頻 度を比較したところ, ダルテパリン単独投与群がワー ファリン投与群より有意に低下したと報告している (17\% vs. 9\%, p=0.002). しかし日本では, VTEに対す る保険適応が認められておらず，わが国のガイドライン では低用量未分画へパリン, 用量調節未分画へパリン, 用量調節ワーファリンを推奨している.14 本検討では, ワーファリンによる抗凝固療法を行ったところ, 出血な どの副作用はみられなかったが, 11 例中約半数で治療効 果が得られず，さらに悪化した 4 例中 3 例において, PTE が直接死因となっており, 有効な治療法とは言い難 い結果であった。一方, PTEにおける血栓溶解療法は抗 凝固療法単独に比べて, より早期の血栓溶解効果や血行 動態改善効果が明らかに示されているものの, 死亡率や 再発率の低下は示されていない. 15 したがって血栓溶解 療法の適応は, ショックや低血圧を認める血行動態の不 安定な症例で, 出血のリスクを十分に考慮した上で使用 するべきと考えられ, 本検討でもショックを伴った PTE 合併肺癌の 1 例に対して, ウロキナーゼを使用し, 著明 な臨床症状の改善が得られたが, PTE 発症から 4 ケ月後 に肺癌の進行により死亡した. また,下大静脈フィルター 留置による PTEの予防効果に関しては, 中枢側の DVT に対して急性期のみならず慢性期においても認められて いる.しかし同時に, DVT の再発も増加することが指摘 されている. 16 本検討では, 4 例に下大静脈フィルターを 留置し, 抗凝固療法を行うも, 3 例が悪化し, うち 2 例で PTEの再発および進行を認めた. したがって，下大静脈 フィルター留置は, 抗凝固剤に対する相対的禁忌がある 場合, 抗凝固剂が無効な場合, 抗凝固剤の合併症が出現 した場合，四肢血管エコーで浮遊血栓が確認された場合 などに適応を考慮すべきと考えられる.

VTE 合併肺癌の予後および死因に関して, 肺癌患者に おいて血栓塞栓症発症から死亡までの平均生存期間が 24 週であったとする報告がみられる. 17 また, Chew ら 3 の報告では, 1 年間の観察期間中に原発性肺癌患者の約 $3 \%$ にTEを認め, また, その死因の $75 \%$ が肺癌の進行 によるもので, VTE による死亡はわずか $2 \%$ であったこ とから, VTEの合併は, 再発あるいは進行性肺癌を示唆 するもので，予後不良因子と考えられる，本検討におい ても, VTE 合併肺癌の予後は, 非合併肺癌と比べて有意 に不良であり, VTE 発症からの平均生存期間は 20.9 週 と短いものであった。 また, VTE 合併肺癌の死因は, 肺 癌の進行によるものが 12 例中 7 例と最多で, そのうち
VTE 自体は, 治療により 5 例で改善が認められていたこ とより, VTEを合併した際の肺癌は予後不良であること が示唆された，一方，VTEが原因で死亡した 3 例は，い ずれも PTEの再発であり, PTEのコントロールが生存 期間を左右する重要な点であると考えられた.

以上, VTE 合併肺癌症例は, 抗癌剂治療に抵抗性を示 し，予後不良であった。 さらにワーファリンによる抗凝 固療法の効果がそしい症例の中には, PTE が直接死因と なっているものも存在するため, 今後は早期治療効果を 期待した血栓溶解療法や, 低分子へパリンなどの積極的 な使用を考慮し, 患者の予後ならびに QOL の改善を図 るべきと考えられる。

\section{REFERENCES}

1. Goldhaber SZ. Pulmonary embolism. Lancet. 2004;363: 1295-1305.

2. Heit JA, Silverstein MD, Mohr DN, Petterson TM, O'Fallon WM, Melton LJ 3rd. Risk factors for deep vein thrombosis and pulmonary embolism: a population-based case-control study. Arch Intern Med. 2000;160:809-815.

3. Chew HK, Davies AM, Wun T, Harvey D, Zhou H, White $\mathrm{RH}$. The incidence of venous thromboembolism among patients with primary lung cancer. J Thromb Haemost. 2008;6:601-608.

4. Blom JW, Osanto S, Rosendaal FR. The risk of a venous thrombotic event in lung cancer patients: higher risk for adenocarcinoma than squamous cell carcinoma. J Thromb Haemost. 2004;2:1760-1765.

5. 日本肺癌学会. III. 定義と解説. 臨床 - 病理 肺癌取扱 い規約. 第 6 版. 東京：金原出版；2003:122-123.

6. Loreto MF, De Martinis M, Corsi MP, Modesti M, Ginaldi L. Coagulation and cancer: implications for diagnosis and management. Pathol Oncol Res. 2000;6:301-312.

7. Wahrenbrock M, Borsig L, Le D, Varki N, Varki A. Selectin-mucin interactions as a probable molecular explanation for the association of Trousseau syndrome with mucinous adenocarcinomas. J Clin Invest. 2003;112: 853-862.

8. Bick RL. Cancer-associated thrombosis. N Engl J Med. 2003;349:109-111.

9. Khorana AA, Francis CW, Culakova E, Lyman GH. Risk factors for chemotherapy-associated venous thromboembolism in a prospective observational study. Cancer. 2005;104:2822-2829.

10. Kuroiwa M, Okamura T, Kanaji T, Okamura S, Harada $\mathrm{M}$, Niho Y. Effects of granulocyte colony-stimulating factor on the hemostatic system in healthy volunteers. Int $J$ Hematol. 1996;63:311-316.

11. Hutten BA, Prins MH, Gent M, Ginsberg J, Tijssen JG, Büller HR. Incidence of recurrent thromboembolic and bleeding complications among patients with venous thromboembolism in relation to both malignancy and achieved international normalized ratio: a retrospective analysis. J Clin Oncol. 2000;18:3078-3083.

12. Prandoni P, Lensing AW, Piccioli A, Bernardi E, Simioni 
P, Girolami B, et al. Recurrent venous thromboembolism and bleeding complications during anticoagulant treatment in patients with cancer and venous thrombosis Blood. 2002;100:3484-3488.

13. Lee AY, Levine MN, Baker RI, Bowden C, Kakkar AK Prins M, et al. Low-molecular-weight heparin versus a coumarin for the prevention of recurrent venous thromboembolism in patients with cancer. $N$ Engl J Med. 2003; 349:146-153.

14. 肺血栓塞栓症/深部静脈血栓症（静脈血栓塞栓症）予防ガ イドライン作成委員会. 総論. 肺血栓塞栓症/媣部静脈血 栓症 (静脈血栓塞栓症) 予防ガイドライン。東京：メディ カルフロントインターナショナルリミテッド ; 2004:7584 .
15. Thabut G, Thabut D, Myers RP, Bernard-Chabert B, Marrash-Chahla R, Mal H, et al. Thrombolytic therapy of pulmonary embolism: a meta-analysis. J Am Coll Cardiol. 2002;40:1660-1667.

16. PREPIC Study Group. Eight-year follow-up of patients with permanent vena cava filters in the prevention of pulmonary embolism: the PREPIC (Prévention du Risque d'Embolie Pulmonaire par Interruption Cave) randomized study. Circulation. 2005;112:416-422.

17. Putterman C, Tadmor B, Simer L, Caraco Y. Recurrent venous thrombosis as the presenting sign of two primary lung carcinomas--15 years apart. Respir Med. 1992; 86:521-523. 